\title{
Development of Upwelling during the Sedimentary Period of the Organic-Rich Shales in the Wufeng and Longmaxi Formations of the Upper Yangtze Region and Its Impact on Organic Matter Enrichment
}

\author{
Shao-Ze Zhao ${ }^{1}$, Yong Li ${ }^{1,2, *}$, Hua-Jun Min ${ }^{1,2}{ }^{\oplus}$, Tong Wang ${ }^{3}$, Zhou Nie ${ }^{4}$, Zhan-Zhao Zhao ${ }^{5}$, \\ Jia-Zhen $\mathrm{Qi}^{6}{ }^{6}$, Jin-Cheng Wang ${ }^{7}$ and Jia-Peng $\mathrm{Wu}^{7}$ \\ 1 State Key Laboratory of Oil and Gas Reservoir Geology and Exploitation, Chengdu University of Technology, \\ Chengdu 610059, China; zszcdut@126.com (S.-Z.Z.); minesky@126.com (H.-J.M.) \\ 2 College of Energy Resources, Chengdu University of Technology, Chengdu 610059, China \\ 3 Sinopec Southwest Oil and Gas Company, Chengdu 610016, China; wangtong1.xnyq@sinopec.com \\ 4 PetroChina Southwest Oil and Gas Field Company, Chengdu 610051, China; niezhou@petrochina.com.cn \\ 5 PetroChina Logging Co., Ltd., Xi'an 710077, China; szzhaozhzh@cnpc.com.cn \\ 6 Sinopec Shanghai Offshore Oil \& Gas Company, Shanghai 200120, China; qijiazhen.shhy@sinopec.com \\ 7 PetroChina Dagang Oilfield Company, Tianjin 300280, China; wangjcheng@petrochina.com.cn (J.-C.W.); \\ wujpeng@petrochina.com.cn (J.-P.W.) \\ * Correspondence: liy@cdut.edu.cn; Tel.: +86-028-840-79759
}

Received: 3 March 2019; Accepted: 7 April 2019; Published: 11 April 2019

\begin{abstract}
This study uses logging data, mineral component content, total organic carbon (TOC) content, and microscopic characteristics of the organic-rich shales in the Wufeng and Longmaxi Formations, as well as data reported by other researchers, to demonstrate that upwelling has played an important role in the organic matter enrichment. The results show that (1) the organic-rich shales of Well N211 in the Upper Yangtze region are located in the Wufeng Formation and the lower Longmaxi Formation, with a burial depth between 2308-2357 m. (2) The organic-rich shales are enriched in biogenic silica. (3) Based on paleogeographic location and characteristics of organisms, this study determines that upwelling occurred during the deposition of the organic-rich shales in the Wufeng and Longmaxi Formations, promoting the enrichment of organic matter in the shales. (4) The upwelling intensity gradually increased from the sedimentary period of the organic-rich shales in the mid-lower Wufeng Formation to the sedimentary period of the Guanyinqiao Member, and then decreased gradually from the sedimentary period of the Guanyinqiao Member to the sedimentary period of the organic-rich shales in the Longmaxi Formation, and leads to the different enrichment of organic matter in the vertical direction. The different developments of upwelling led to the coexistence of both high and low TOC contents in the Guanyinqiao Member along the vertical direction.
\end{abstract}

Keywords: the Upper Yangtze region; the Wufeng and Longmaxi Formations; organic-rich shales; silica characteristics; upwelling

\section{Introduction}

Recently, with the vigorous development of shale gas production, the formation mechanism and pattern of organic-rich shales have become topics of considerable interest in current research [1,2]. The Wufeng and Longmaxi Formations are one of the main strata for the exploration and development of shale gas in South China. Previous scholars have conducted a large number of studies on the formation mechanism of this series of organic-rich shales. It is generally believed that the organic-rich shales 
in the Wufeng and Longmaxi Formations formed under the sedimentary background of an anoxic environment and high productivity [2-8], and that the semi-closed environment or rapid transgression was the main reason for the anoxic environment [2-5]. Studies on the cause of high paleo-productivity are scarce in the current literature. Lu et al. [9] and Wu et al. [10] suggested that volcanic ash provided abundant nutrients for marine organisms and played a positive role in the enhancement of marine surface primary productivity, providing a material basis for the organic-rich shales in the Wufeng and Longmaxi Formations. Modern marine research shows that upwelling plays an important role in enhancing marine surface primary productivity. Upwelling brings nutrients from the deep-sea to the shallow-sea euphotic zone, making the zone highly productive. The upwelling-induced high primary productivity played an important role in the formation of organic-rich shales during the geological periods. For example, Pedersen and Calvert [11] suggested that the upwelling-related high productivity is more important to the formation of hydrocarbon source rocks than the anoxic environment and that the input of organic matter is the main factor in the formation of organic-rich shales. Currently, studies on the contribution of upwelling to the organic-rich shales in the Wufeng and Longmaxi Formations remain scarce. This study analyses the vertical changes and silica characteristics of the organic-rich shales in the Wufeng and Longmaxi Formations using logging data, mineral component content, total organic carbon (TOC) content, and microscopic characteristics. Finally, by combining the results from this work with the data reported by other researchers, our study preliminarily discusses the development conditions of upwelling during the sedimentary period of the organic-rich shales in the Wufeng and Longmaxi Formations of the study area and suggests that upwelling played an important role in the formation of the organic-rich shales in the Wufeng and Longmaxi Formations.

\section{Geological Setting}

During the late Ordovician-early Silurian, the Yangtze region was a part of the South China Block, which was located at the tropical or subtropical area near the equator at the western margin of the Gondwana continent [12] (Figure 1a). Due to the influence of the Guangxi movement since the late Ordovician, the paleo-uplifts at the continental margin, such as the central Sichuan submarine uplift and central Guizhou uplift, turned the Yangtze sea area with its open-ocean characteristics, during the early-mid Ordovician, into a restricted shallow sea that was surrounded by uplifts, forming a large area of low-energy and under-compensation in an anoxic environment $[1,13,14]$.

The organic-rich shales in the Wufeng and Longmaxi Formations only accounts for approximately $8-20 \%$ of the stratum thickness. The maximum thickness of the stratum with a TOC greater than $2 \%$ is $100 \mathrm{~m} \mathrm{[1],} \mathrm{which} \mathrm{is} \mathrm{located} \mathrm{at} \mathrm{the} \mathrm{lower} \mathrm{end} \mathrm{of} \mathrm{the} \mathrm{strata} \mathrm{(Figure} \mathrm{1b,c).} \mathrm{The} \mathrm{thickness} \mathrm{of} \mathrm{the}$ Wufeng Formation is generally less than $30 \mathrm{~m}$. However, this stratum is widely distributed. The main compositions are grey-black shale and siliceous shale. The variation of the thickness of the Longmaxi Formation is large, ranging from $55-516 \mathrm{~m}$. The primary constituents of this formation are black shale, siliceous shale and silty shale (Figure 2a-c) [13-15]. The Guanyinqiao Member of the top Wufeng Formation is divided into three lithofacies in the Upper Yangtze region; siliceous shale facies, calcareous siliceous shale facies (Figure 2a,b), and limestone facies. The siliceous shale and calcareous siliceous shale in the Guanyinqiao Member are high in TOC content and gamma ray (GR) value, whereas the limestone in the Guanyinqiao Member is low in TOC content and GR value [16]. The Guanyinqiao Member is a set of regionally distributed lumachelle that formed during the Hirnantian age with a small thickness and high abundance of Hirnantian Brachiopoda fossils (Figure $2 \mathrm{~d}-\mathrm{f}$ ), indicating that formation occurred in a seawater environment that was cold, regressional, shallow, and bottom oxygen-rich [17]. Due to the effect of volcanic activities, the organic-rich shales in the Wufeng and Longmaxi Formations is intercalated with multiple layers of K-bentonites (Figure 2g). K-bentonites are from altered volcanic ash and composed almost entirely of clay minerals, with a smooth and silky texture. The K-bentonite layers in outcrops are light-yellow to dark-yellow. 

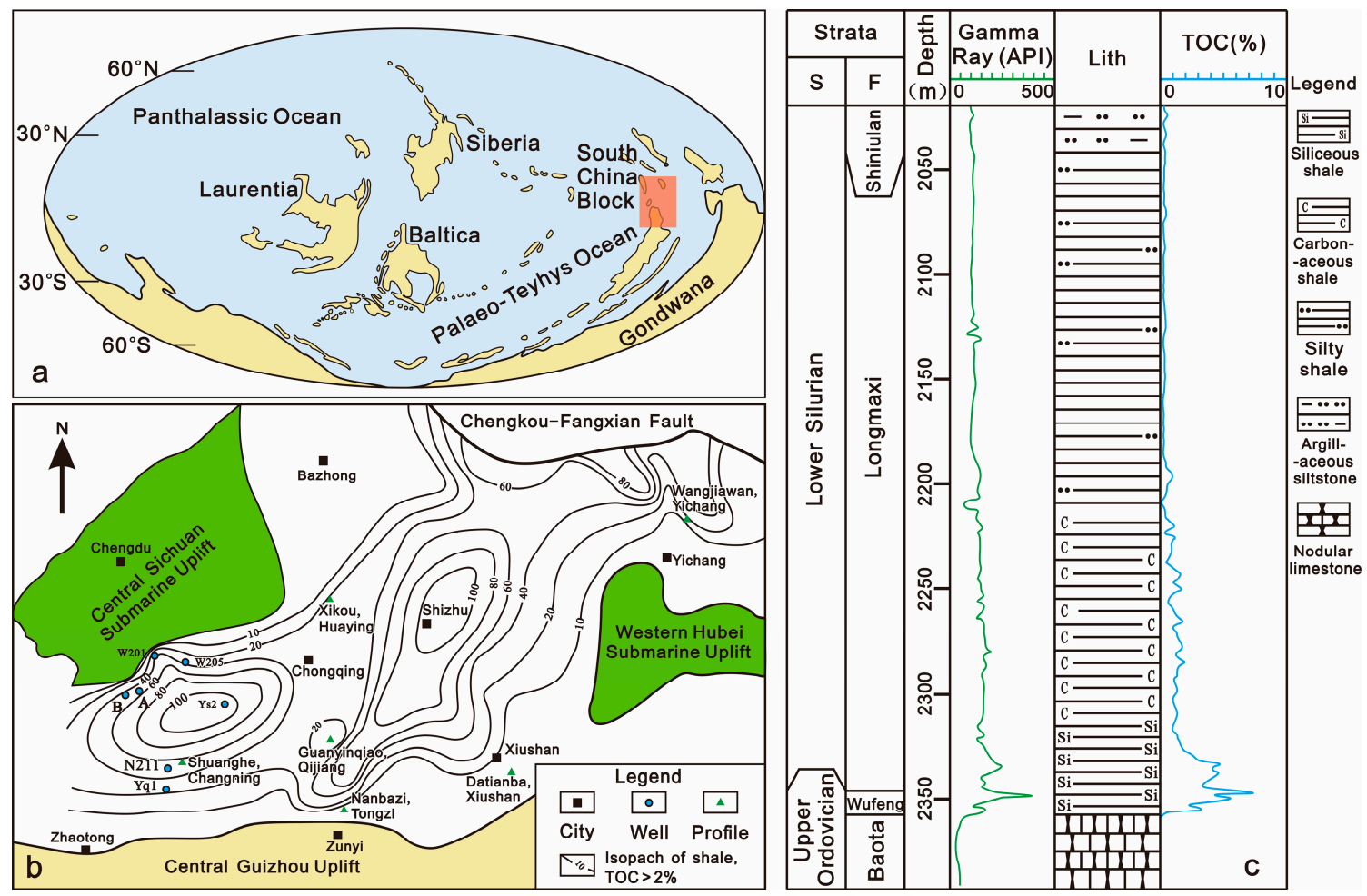

Figure 1. (a) Location of the South China Block (based on the results of Zhou et al. [12]); (b) distribution of the Upper Yangtze organic-rich shales (based on the results of Wang et al. [1]); and (c) stratigraphic profile of the Wufeng and Longmaxi Formations of Well N211.
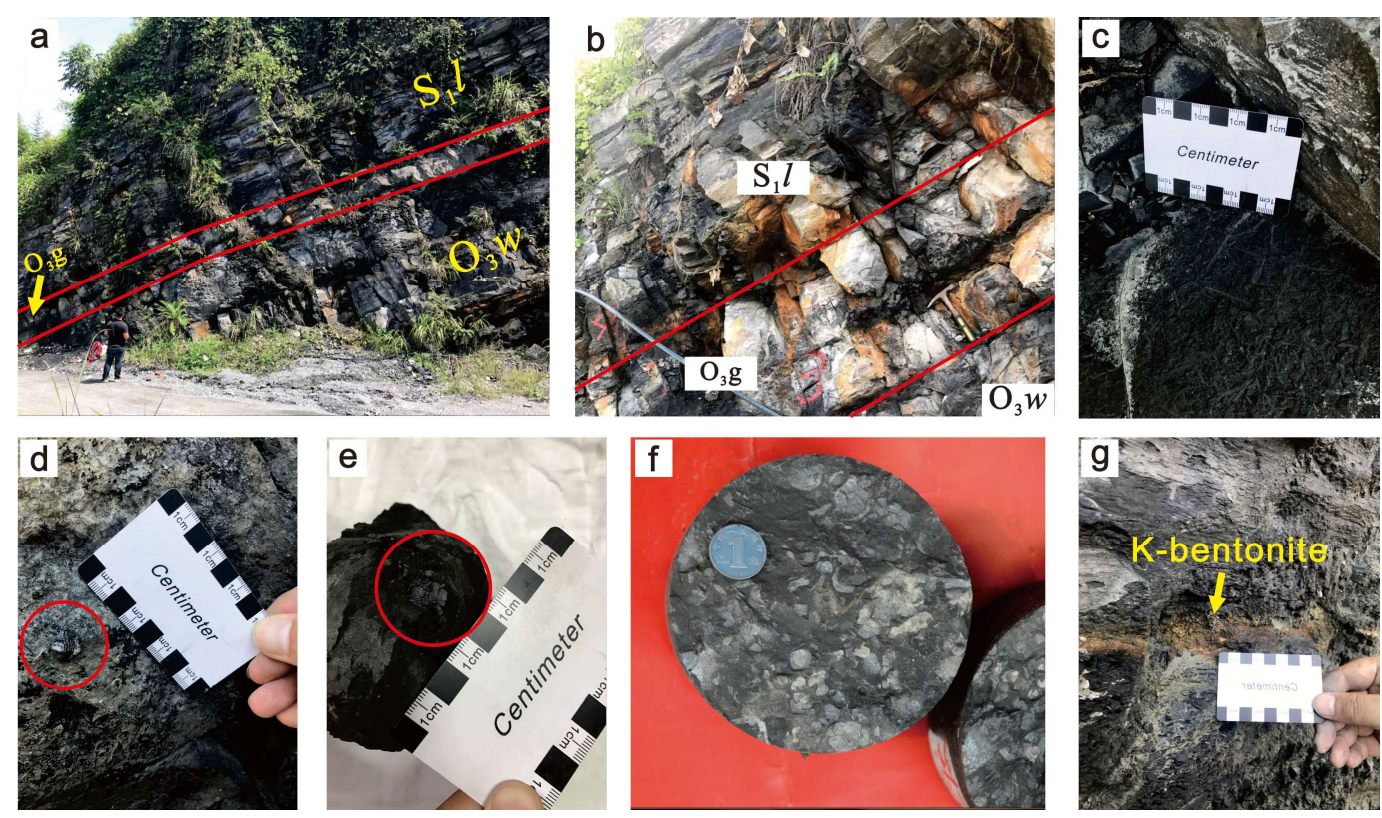

Figure 2. Field and rock core photographs of the organic-rich shales in the Wufeng and Longmaxi Formations of the Upper Yangtze region. (a) Continuous deposition of organic-rich shales in the Wufeng Formation $\left(\mathrm{O}_{3} w\right)$ and Longmaxi Formation $\left(\mathrm{S}_{1} l\right) ;(\mathbf{b})$ calcareous siliceous shales in the Guanyinqiao Member $\left(\mathrm{O}_{3} g\right)$; (c) siliceous shales in the Wufeng Formation with a large number of graptolites; (d-f) calcareous siliceous shales in the Guanyinqiao Member with a large number of Hirnantian Brachiopoda fossils; (g) intercalated layers of K-bentonites. (a-e,g) Are photographs of the Shuanghe profile, (f) is a photograph of a rock core from Well A. 


\section{Materials and Methods}

The logging data of Well N211 in the Upper Yangtze region, along with mineral component content, TOC content, GR value, uranium (U) content, and gas content, were used to investigate the vertical variation characteristics of the organic-rich shales in the Wufeng and Longmaxi Formations. Mineral component content and TOC content were measured by the element capture spectroscopy (ECS), which can measure the relative content of $\mathrm{C}, \mathrm{O}, \mathrm{Si}, \mathrm{Ca}, \mathrm{Fe}, \mathrm{S}, \mathrm{Ti}, \mathrm{Gd}$, and other elements. Then the oxide closure model was used to determine the mineral content and TOC content. The GR value and U content were measured by natural gamma spectrometry logging (NGS). Based on the core calibrated isothermal adsorption curve, the adsorbed gas content in the formation can be calculated by using the formation temperature and pressure, which were obtained by logging. On the basis of accurate clay mineral content, type, and formation porosity, the free gas content can be obtained by using the dual-water model and ELAN-plus optimization interpretation program. The data was collected by Schlumberger. In order to better analyze the silica characteristics, we systematically collected 35 organic-rich shale samples from the Wufeng and Longmaxi Formations of Upper Yangtze Wells A and B, among which 20 were from Well A, and 15 were from Well B. The sampling depth of well A was between 3815-3840 m, and the sampling depth of well B was between 3890-3905 m. The sampling interval of wells A and B was lower than $2 \mathrm{~m}$. After rinsing multiple times using deionized water, followed by drying, the samples were manually ground to particles finer than 80 mesh, as required for TOC analysis and mineral component analysis. TOC analysis was carried out with a CS-344 carbon-sulfur analyzer (Leco, San Jose, CA, USA). Mineral component analysis was carried out with a BTX-563 X-ray diffractometer (Olympus, Tokyo, Japan). All of the above tests were completed at the College of Energy Resources, Chengdu University of Technology. The shale microscopic characteristics were analyzed for a subset of the samples from Well A, Well B, and the Shuanghe profile, based on thin sections and scanning electron microscopy (SEM). The thin sections were analyzed using Leica DM4500P polarized light microscope (Leica, Wetzlar, Germany). The SEM analysis was carried out with a Quanta 250 FEG scanning electron microscope (Fei, Hillsboro, OR, USA) and an Oxford INCAx-max20 spectrometer (Oxford Instruments, Oxford, UK). The microscopic characteristics analysis was carried out at the State Key Laboratory of Oil and Gas Reservoir Geology and Exploitation.

\section{Results and Discussion}

\subsection{Vertical Change Characteristics of the Organic-Rich Shales in the Wufeng and Longmaxi Formations}

The shales between the upper Ordovician Wufeng Formation and lower Silurian Longmaxi Formation are as thick as 500-600 m, whereas the organic-rich shales reside mainly in the Wufeng Formation and the lower Longmaxi Formation, which is siliceous shale or silica-bearing shale $[1,6,10]$. This study mainly investigated logging data from Upper Yangtze Well N211, as an example to demonstrate the vertical changes of the organic-rich shales in the Wufeng and Longmaxi Formations. The organic-rich shales of Well N211 are located at the Wufeng Formation and the lower Longmaxi Formation, with a burial depth between $2308-2357 \mathrm{~m}$. This shale section could be generally divided into two layers. The first layer with a burial depth between $2333-2357 \mathrm{~m}$, the second layer with a burial depth between 2308-2333 m; the TOC content of the first layer was generally higher than that of second layer.

The TOC content of the shale layer with a burial depth between $2333-2357 \mathrm{~m}$ was high, with a range of $1.2-7.7 \%$ and an average of $4.1 \%$. The GR value and U content were also high. The GR value was between 98-396 API with an average of 185 API. The U content was between 2-40 ppm with an average of $14.8 \mathrm{ppm}$. The mineral component content shows that the clay content was low, with a range of $11-38 \%$ and an average of $18 \%$. In addition, the silica content was high, with a range of $36-64 \%$ and an average of $50.9 \%$. The carbonate content was between $0-37 \%$, with an average of $16 \%$. The pyrite content was less than $6.4 \%$. With a stratigraphic pressure coefficient of 2.0 , the adsorbed gas, 
free gas, and total gas contents were approximately $1.67,3.51$, and $5.18 \mathrm{~m}^{3} /$ ton, respectively (Table 1 ). The Guanyinqiao Member at the top of the Wufeng Formation was siliceous shale, with a thickness of approximately $1.0 \mathrm{~m}$. The logging TOC content was up to $7.7 \%$. The peak responses of the TOC-related GR value and U content in the Guanyinqiao Member were 396 API and 40 ppm, respectively. The silica content peaked at $64 \%$, which was significantly higher than that of the mid-lower Wufeng Formation or lower Longmaxi Formation. The TOC content, GR value, U content, and silica content at this section increased gradually from the lower Wufeng Formation to the Guanyinqiao Member, reaching their maxima in the Guanyinqiao Member before decreasing gradually from the Guanyinqiao Member to the Longmaxi Formation (Figure 3). The $\mathrm{P}_{2} \mathrm{O}_{5} / \mathrm{TiO}_{2}$ ratio is a common proxy for paleoceanic nutrient status [6]. The $\mathrm{P}_{2} \mathrm{O}_{5} / \mathrm{TiO}_{2}$ value of the Well $\mathrm{N} 211$ organic-rich shales showed a peak value in the Guanyinqiao Member [1], indicating that the sea surface nutrient concentration reached a maximum during the sedimentary period of the Guanyinqiao Member. In addition, the productivity proxy (biogenic Ba content) in the profile of Wangjiawan also peaks in the Guanyinqiao Member $[17,18]$.

Table 1. Well N211 logging data.

\begin{tabular}{|c|c|c|c|c|c|c|c|c|c|c|}
\hline $\begin{array}{c}\text { Layer } \\
\text { Number }\end{array}$ & Depth (m) & $\begin{array}{c}\text { Gamma } \\
\text { Ray } \\
\text { (API) }\end{array}$ & $\begin{array}{c}\text { Uranium } \\
\text { Content } \\
\text { (ppm) }\end{array}$ & $\begin{array}{c}\text { Total } \\
\text { Organic } \\
\text { Carbon } \\
\text { Content (\%) }\end{array}$ & $\begin{array}{c}\text { Clay } \\
\text { Content } \\
(\%)\end{array}$ & $\begin{array}{c}\text { Silica } \\
\text { Content } \\
(\%)\end{array}$ & $\begin{array}{l}\text { Carbonate } \\
\text { Content } \\
(\%)\end{array}$ & $\begin{array}{l}\text { Adsorbed } \\
\text { Gas } \\
\text { Content } \\
\left(\mathrm{m}^{3} / \text { ton }\right)\end{array}$ & $\begin{array}{l}\text { Free Gas } \\
\text { Content } \\
\left(\mathrm{m}^{3} / \text { ton }\right)\end{array}$ & $\begin{array}{l}\text { Total } \\
\text { Gas } \\
\text { Content } \\
\left(\mathrm{m}^{3} / \text { ton }\right)\end{array}$ \\
\hline 2 & $2308-2333$ & 160 & 5.9 & 2 & 34.3 & 50 & 7.2 & 0.69 & 2.66 & 3.35 \\
\hline
\end{tabular}

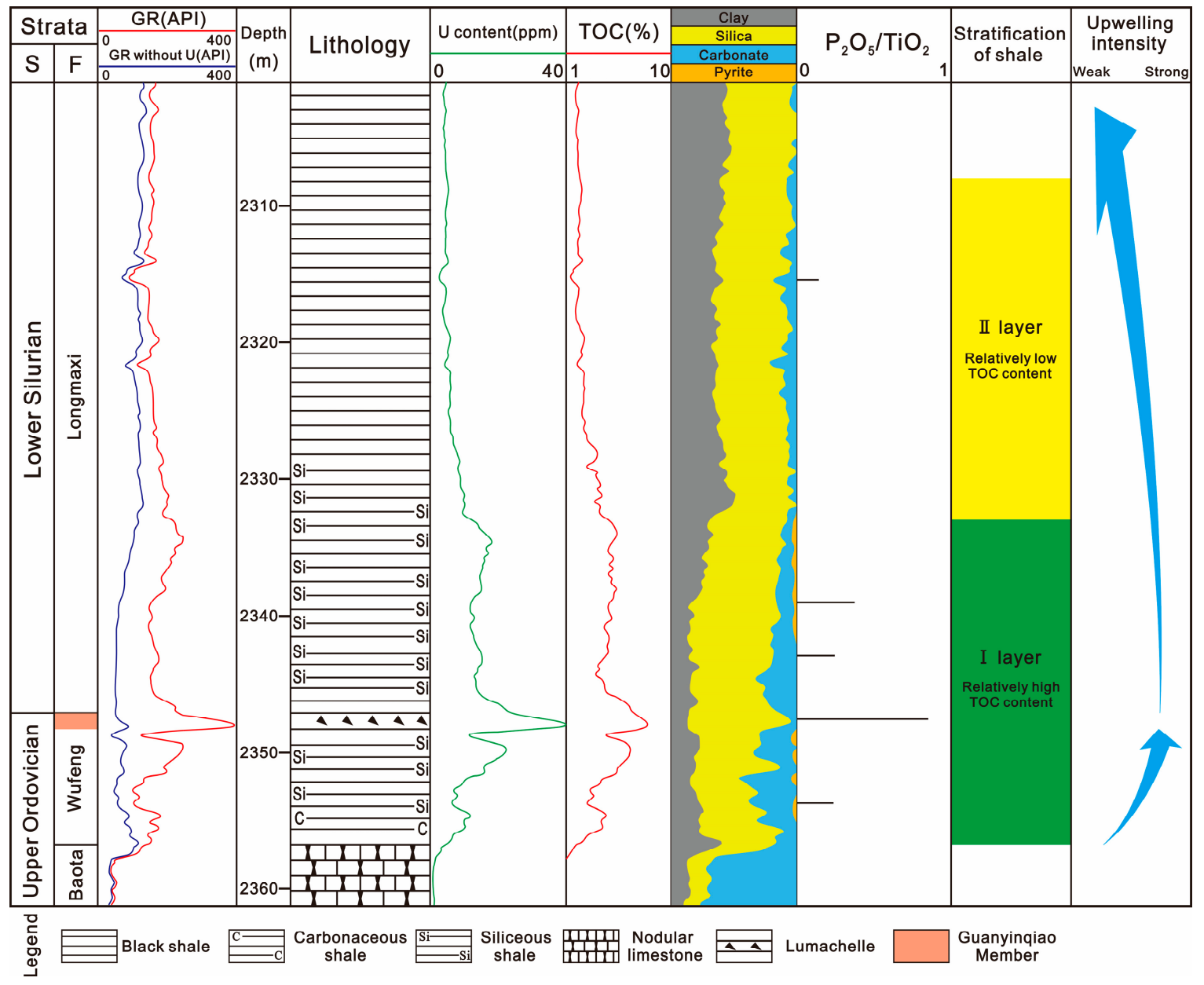

Figure 3. Comprehensive stratigraphic profile of Upper Yangtze Well N211 (the $\mathrm{P}_{2} \mathrm{O}_{5} / \mathrm{TiO}_{2}$ ratio is from the results of Wang et al. [1]). 
The TOC content of the second shale layer with a burial depth between 2308-2333 m was slightly less, with a range of $0.5-3.9 \%$ and an average of $2.0 \%$. The GR value and $U$ content were poorer than the first layer. The GR value was between 92-211 API with an average of 160 API, and the U content was between 3-12 ppm with an average of $5.9 \mathrm{ppm}$. The clay content was higher than that of the first layer, with a range of $27-44 \%$ and an average of $34 \%$. The silica content was generally identical to that of the first layer, with a range of $39-56 \%$ and an average of $50 \%$. The carbonate content was quite low, with a range of $0-21 \%$ and an average of $7.2 \%$. With a stratigraphic pressure coefficient of 2.0, the adsorbed gas, free gasm and total gas contents were approximately $0.69,2.66$, and $3.35 \mathrm{~m}^{3} /$ ton, respectively. Compared to the first layer, the adsorbed gas content and the free gas content of the second layer were both lower (Table 1). In general, the TOC content, GR value, and U content gradually decreased from $2033 \mathrm{~m}$ upward (Figure 3).

\subsection{Silica Characteristics of the Organic-Rich Shales in the Wufeng and Longmaxi Formations}

The mineral component content of the organic-rich shales in the Wufeng and Longmaxi Formations of Upper Yangtze Wells A and B (Table 2) showed that the main mineral components of this shale set were mainly clay, quartz, and carbonate, and the results were similar to those obtained from logging data. Clay content was between $19.4-57.1 \%$, with an average of $37.1 \%$. The quartz content was high, with a range of $17.9-68.5 \%$ and an average of $34.4 \%$, which was the main form of silica. Feldspar was another form of silica, and its content was generally low and varies slightly from $0.8-5.8 \%$, with an average of $2.8 \%$. The TOC content was high, with a range of $1.65-6.04 \%$ and an average of $2.90 \%$ (Table 2). Quartz may be derived from siliceous organisms or terrigenous material. Clay and feldspar generally represent the input of terrigenous material. The quartz content in well B was mainly between $20-70 \%$, and the clay + feldspar content was mainly between $20-50 \%$, the clay + feldspar content and the quartz content were negatively correlated $\left(R^{2}=0.63, p=0.000\right)$ (Figure $\left.4 a\right)$. The quartz content in well A was mainly between $20-40 \%$, with a small range of variation, and the clay + feldspar content was between $30-60 \%$, and there was no obvious correlation between the clay + feldspar content and the quartz content $\left(\mathrm{R}^{2}=0.0016\right)$ (Figure $\left.4 \mathrm{a}\right)$, and $p=0.867>0.05$, suggesting that there was no statistical correlation between the two factors. The residuals did not have the tendency of normal distribution in the standardized residual histogram. It could also be concluded that there was no statistical correlation between the clay + feldspar content and the quartz content. Either negative correlation or nearly no correlation, all suggest that terrigenous input has little impact on the quartz fraction in the organic-rich shales. Compared with the samples of well B, the samples of well A might be affected relatively bigger by the terrigenous material; therefore, there was no correlation between the clay + feldspar content and the quartz content in well A. TOC generally represents input of organic matter, the TOC content in well $\mathrm{B}$ was between $2-7 \%$, and there was an obvious positive correlation between quartz content and TOC content $\left(\mathrm{R}^{2}=0.60, p=0.001\right)$ (Figure $4 \mathrm{~b}$ ), indicated that quartz might be biogenic. The TOC content of well A was between 1-5\%, and there was also a positive correlation between quartz content and TOC content $\left(\mathrm{R}^{2}=0.41, p=0.002\right)$, but the correlation was relatively poor compared with well B (Figure $4 b$ ), which might be caused by the input of terrigenous quartz. All the above analysis of correlation suggest that quartz might be mainly biogenic. 
Table 2. Mineral components and TOC content of the organic-rich shales in the Wufeng and Longmaxi Formations of Upper Yangtze Wells A and B.

\begin{tabular}{|c|c|c|c|c|c|c|c|c|}
\hline Well No. & $\begin{array}{l}\text { Sampling } \\
\text { Depth (m) }\end{array}$ & Clay (\%) & $\begin{array}{c}\text { Quartz } \\
(\%)\end{array}$ & $\begin{array}{c}\text { Feldspar } \\
(\%)\end{array}$ & $\begin{array}{c}\text { Carbonate } \\
(\%)\end{array}$ & $\begin{array}{c}\text { Pyrite } \\
(\%)\end{array}$ & $\begin{array}{c}\text { Other } \\
\text { Minerals (\%) }\end{array}$ & TOC (\%) \\
\hline \multirow{20}{*}{ Well A } & 3815.9 & 51.1 & 34.2 & 3.6 & 4.8 & 4.3 & 2.0 & 2.33 \\
\hline & 3817.6 & 39.5 & 25.1 & 4.3 & 27.4 & 1.9 & 1.8 & 2.57 \\
\hline & 3818.7 & 35.1 & 23.5 & 3.3 & 34.5 & 3.4 & 0.2 & 2.30 \\
\hline & 3820.4 & 32.0 & 27.4 & 1.7 & 35.3 & 2.1 & 1.5 & 1.78 \\
\hline & 3822.1 & 53.6 & 17.9 & 3.2 & 20.1 & 4.0 & 1.2 & 1.65 \\
\hline & 3823.4 & 38.3 & 27.1 & 2.9 & 27.7 & 2.6 & 1.4 & 2.21 \\
\hline & 3825.8 & 35.8 & 32.4 & 3.3 & 24.0 & 3.8 & 0.7 & 2.80 \\
\hline & 3827.7 & 34.4 & 28.7 & 2.0 & 31.6 & 2.2 & 1.1 & 2.33 \\
\hline & 3828.8 & 44.0 & 34.3 & 2.8 & 11.5 & 4.4 & 3.0 & 4.24 \\
\hline & 3829.4 & 37.3 & 38.5 & 2.3 & 15.4 & 3.6 & 2.9 & 3.58 \\
\hline & 3830.0 & 43.2 & 30.4 & 1.7 & 20.5 & 2.9 & 1.3 & 3.36 \\
\hline & 3830.8 & 35.9 & 28.4 & 2.4 & 29.5 & 3.2 & 0.6 & 2.52 \\
\hline & 3831.6 & 37.4 & 24.3 & 2.1 & 32.5 & 3.0 & 0.7 & 1.84 \\
\hline & 3832.4 & 38.6 & 37.1 & 2.3 & 17.7 & 3.4 & 0.9 & 3.74 \\
\hline & 3833.5 & 38.1 & 24.0 & 1.8 & 34.1 & 1.9 & 0.1 & 1.83 \\
\hline & 3834.2 & 33.5 & 21.2 & 0.8 & 38.7 & 4.4 & 1.4 & 1.94 \\
\hline & 3835.8 & 57.1 & 24.3 & 2.6 & 9.5 & 4.3 & 2.2 & 2.44 \\
\hline & 3836.7 & 47.5 & 31.4 & 2.4 & 11.8 & 4.5 & 2.4 & 3.58 \\
\hline & 3837.8 & 41.8 & 42.0 & 3.3 & 6.8 & 4.1 & 2.0 & 3.03 \\
\hline & 3839.1 & 47.9 & 35.1 & 5.5 & 6.0 & 5.1 & 0.4 & 1.70 \\
\hline \multirow{15}{*}{ Well B } & 3890.2 & 39.7 & 34.9 & 5.8 & 13.8 & 3.4 & 2.4 & 2.20 \\
\hline & 3891.0 & 41.0 & 28.4 & 4.1 & 23.2 & 1.6 & 1.7 & 1.71 \\
\hline & 3891.8 & 37.2 & 30.9 & 5.5 & 20.6 & 4.0 & 1.8 & 2.31 \\
\hline & 3892.9 & 33.6 & 44.1 & 5.9 & 13.1 & 2.9 & 0.4 & 2.34 \\
\hline & 3893.8 & 19.4 & 68.5 & 0.8 & 5.1 & 4.8 & 1.4 & 6.04 \\
\hline & 3894.4 & 32.3 & 45.0 & 5.4 & 10.7 & 5.6 & 1.0 & 4.89 \\
\hline & 3894.9 & 24.0 & 59.5 & 2.4 & 8.2 & 4.9 & 1.0 & 3.93 \\
\hline & 3896.0 & 25.1 & 36.1 & 0.9 & 23.2 & 5.4 & 0.3 & 4.47 \\
\hline & 3898.1 & 22.3 & 56.6 & 1.2 & 17.3 & 1.8 & 0.8 & 5.35 \\
\hline & 3899.8 & 31.2 & 30.7 & 2.0 & 29.4 & 4.8 & 1.9 & 3.59 \\
\hline & 3900.3 & 26.9 & 41.3 & 2.3 & 25.1 & 2.6 & 1.8 & 2.85 \\
\hline & 3900.8 & 30.4 & 41.5 & 1.7 & 22.8 & 3.2 & 0.4 & 3.34 \\
\hline & 3902.3 & 33.6 & 43.3 & 2.1 & 16.5 & 3.4 & 1.1 & 3.38 \\
\hline & 3903.6 & 35.7 & 34.0 & 1.6 & 24.3 & 4.2 & 0.2 & 2.94 \\
\hline & 3904.5 & 45.3 & 20.6 & 2.0 & 27.6 & 4.1 & 0.4 & 2.10 \\
\hline Average & - & 37.1 & 34.4 & 2.8 & 20.6 & 3.6 & 1.3 & 2.90 \\
\hline
\end{tabular}
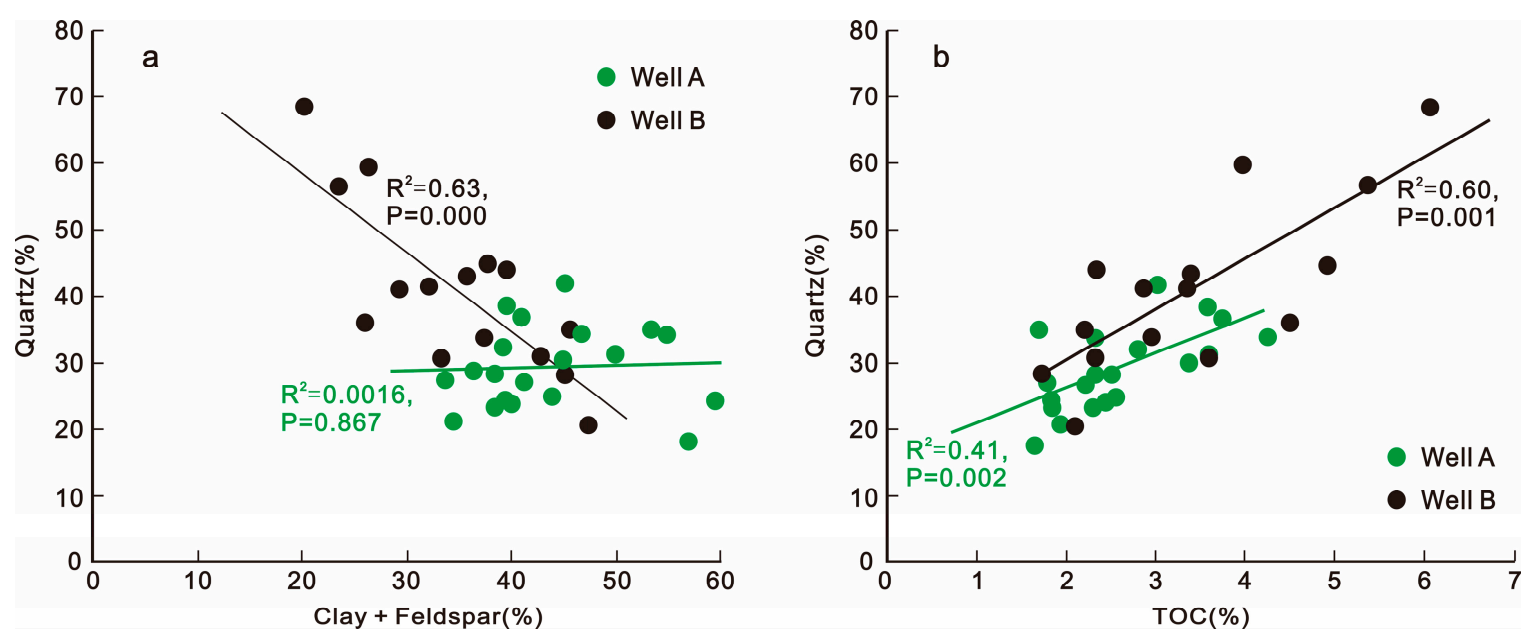

Figure 4. Correlation of quartz with clay + feldspar and TOC in the Wufeng and Longmaxi Formations of the Upper Yangtze region. (a) Correlation of quartz with clay + feldspar; (b) Correlation of quartz with TOC. 
Twelve samples of the organic-rich shales in the Wufeng and Longmaxi Formations were used to analyze the microscopic characteristics. Microscopic observations showed that this shale set was enriched in siliceous organisms such as siliceous Radiolaria (Figure 5a,b) and siliceous sponge spicules (Figure 5c,d); the Radiolaria sizes were between 30-200 $\mu \mathrm{m}$, and the sponge spicules were approximately $500 \mu \mathrm{m}$ long. In particular, the visible range of some shale micrographs indicates that most of the quartz was biogenic. The SEM also clearly showed the ring structure associated with siliceous Radiolaria, of which the outer component was the siliceous skeleton and the inner was organic matter. The siliceous skeletons of Radiolaria were quite thick (Figure 6a), about $10 \mu \mathrm{m}$ thick. Gao et al. [19] and Lu et al. [20] suggested that the thick cyst walls of siliceous Radiolaria reflect their cold-water growth environment. In addition, SEM also showed the existence of numerous quartz granules inside the organic-rich shales, with sizes between 1-5 $\mathrm{m}$. Granular quartz usually co-occured with organic matter, sometimes accompanied by the formation of framboidal shaped pyrite. These particles are elliptical, round, and sub-angular round (Figure $6 \mathrm{~b}-\mathrm{d}$ ), presenting as biogenic opals formed by the water-rock dissolution and re-precipitation of bio-siliceous skeletons [20]. Quartz is a brittle mineral, and its characteristic of co-occurrence with organic matter helps to preserve organic pores.
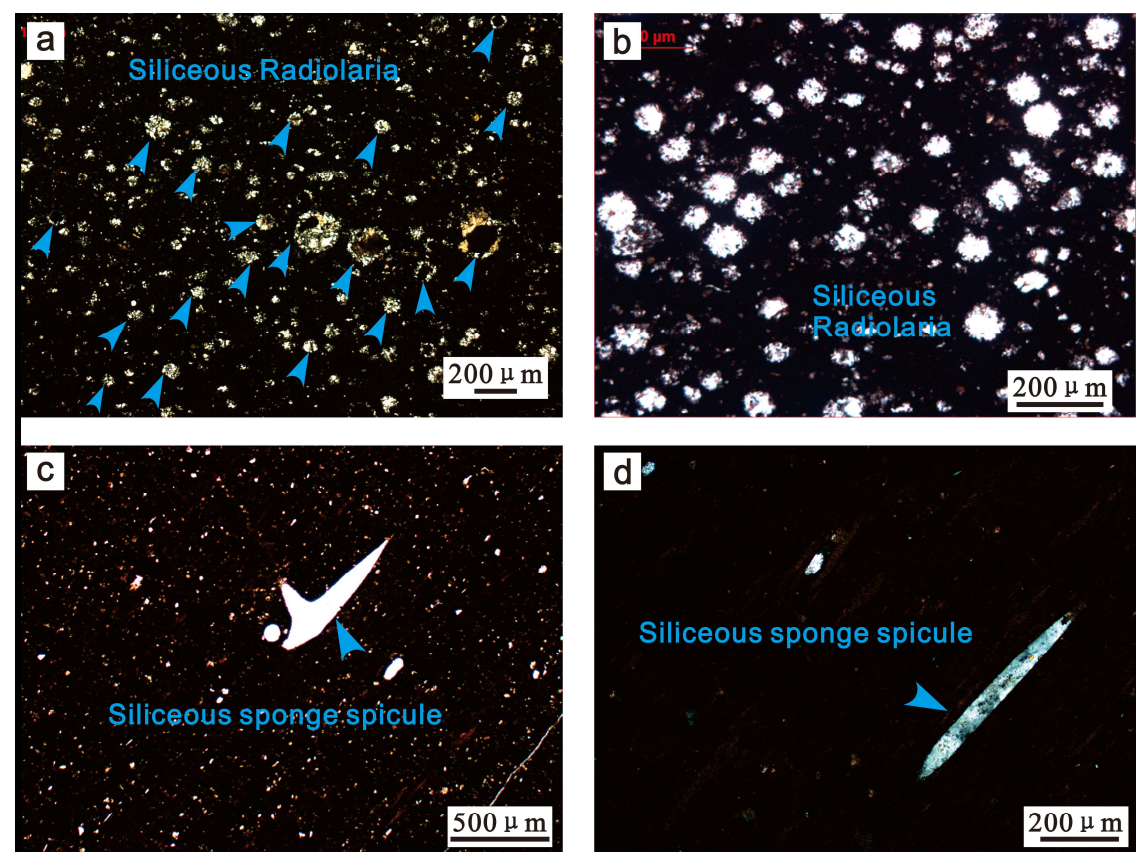

Figure 5. Characteristics of siliceous organisms of the organic-rich shales in the Wufeng and Longmaxi Formations of the Upper Yangtze region shown in thin sections. (a,b) Siliceous radiolaria in the organic-rich shales; (c,d) Siliceous sponge spicule in the organic-rich shales.

Previous studies have investigated the silica sources of the Wufeng and Longmaxi Formations in Jiaoshiba [20,21], Changning [22], Chengkou, Rongxi, and Nanzheng [23] using analysis that included thin section and elemental analysis; these studies determined that the silica in the organic-rich shales is mainly from organisms that are not associated with the terrigenous debris supply. Ma et al. [24] suggested that the content of biogenic quartz from siliceous Radiolaria skeletons and siliceous sponge spicules in the organic-rich shales of the Wufeng and Longmaxi Formations accounts for 67-90\% of the silica content. Therefore, the above study and previous data clearly show that the abundance of silica is not related to terrigenous material input but, rather, is predominantly biogenic. 

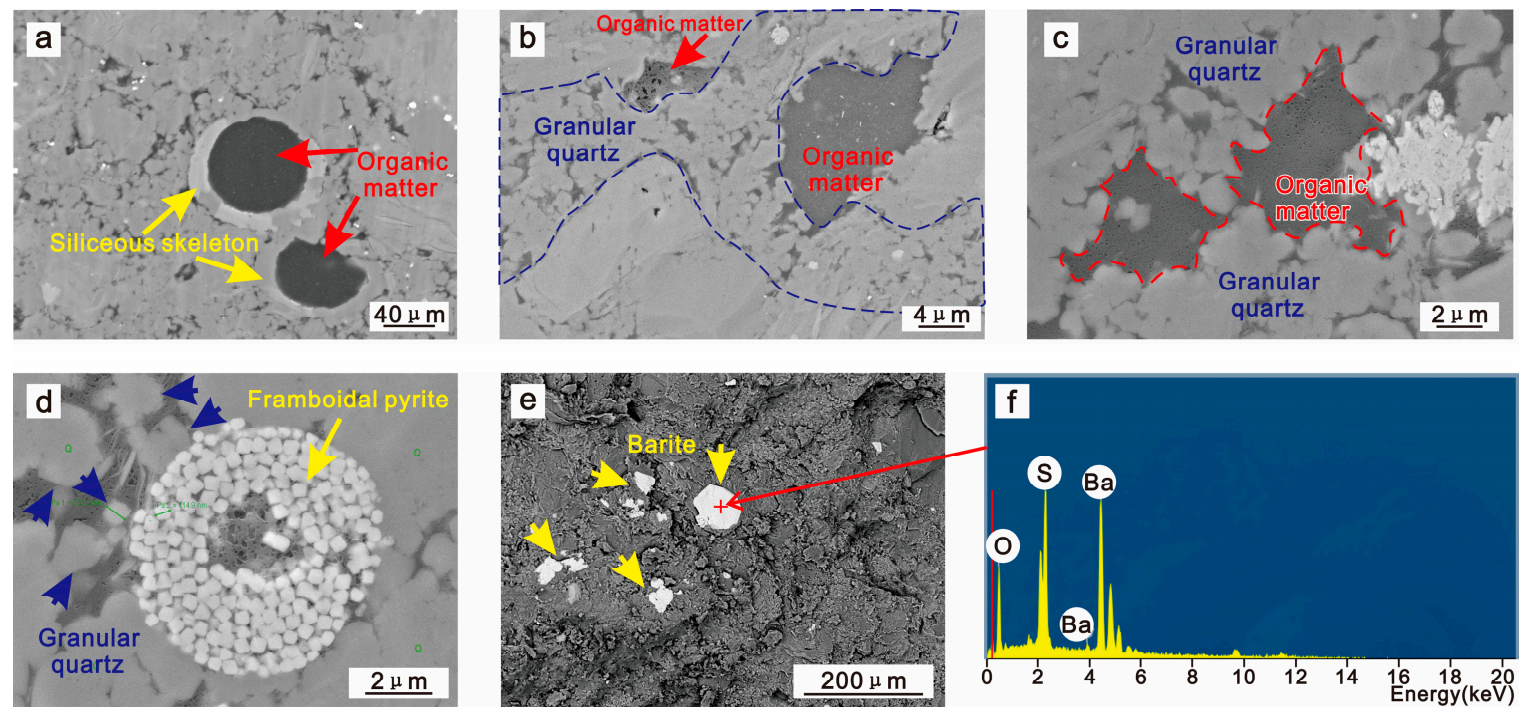

Figure 6. Scanning electron microscopy (SEM) photographs and energy-dispersive spectrum analysis of the organic-rich shales in the Wufeng and Longmaxi Formations of the Upper Yangtze region.

(a) Siliceous Radiolaria in the organic-rich shales; (b-d) Granular quartz co-occured with organic matter;

(e) Barite in the organic-rich shales; (f) Energy spectrum obtained from red cross in photomicrograph (e).

\subsection{The Effects of Sea Level Change and Volcanic Ash on Organic Matter Enrichment}

Qiu et al. [2] suggested that the rise and fall of sea level controls the anoxic degree of bottom water. A fall in sea level leads to oxygen enrichment in bottom water, whereas rising sea levels would result in stratification of the sea, and then lead to anoxia in bottom water. Therefore, sea level controls the degree of organic enrichment in the shales of the Wufeng and Longmaxi Formations in the Wuxi area of the Upper Yangtze region. Due to the large-scale advance and rapid melting of global icecaps during the Ordovician-Silurian boundary period, the sea level change in the Yangtze region associated with the sedimentary period of the organic-rich shales in the Wufeng and Longmaxi Formations is consistent with the global sea level change. Sea level decreased gradually during the sedimentary period of the organic-rich shales in the mid-lower Wufeng Formation, reached a minimum in the sedimentary period of the Guanyinqiao Member, and then increased gradually from the sedimentary period of the Guanyinqiao Member to the sedimentary period of the organic-rich shales in the Longmaxi Formation [16]. The average paleo-water depth of the Upper Yangtze region during the sedimentary period of the Guanyinqiao Member was 20-30 m [25]. In addition, the abundance of Hirnantian Brachiopoda fossils in the Guanyinqiao Member (Figure 2d-f) also indicates the presence of a cold, regressional, bottom oxygen-rich seawater environment [17]. However, according to our observations, the TOC content, GR value, and U content increased gradually from the lower Wufeng Formation to the top Guanyinqiao Member, reached a maximum at the Guanyinqiao Member before decreased gradually from the Guanyinqiao Member to the Longmaxi Formation, which was opposite to the trend followed by the sea level change. Therefore, the change in sea level was not the only factor controlling the organic-rich shales deposition in the Wufeng and Longmaxi Formations. The water depth during the sedimentary period of the Guanyinqiao Member was shallowest, and bottom water was rich in oxygen during that time; however, each parameter peaked in the Guanyinqiao Member, suggesting that the peak of each parameter in the Guanyinqiao Member was not caused by redox conditions due to changes in sea level.

In addition, high sea surface productivity can also lead to organic enrichment in sediment [11] and thus can lead to a series of changes in GR value and U content. Lu et al. [9] and Wu et al. [10] noted that volcanic ash played an important role in increasing the sea surface productivity during the deposition of the organic-rich shales in the Wufeng and Longmaxi Formations. Biogenic barium $\left(\mathrm{Ba}_{\mathrm{bio}}\right)$ is an important proxy of productivity. The detailed SEM observations of the organic-rich shales 
in the Wufeng and Longmaxi Formations of the Shuanghe profile in Changning also showed the existence of barite, the identification of which was based on energy-dispersive spectra (Figure 6e,f). However, the barite occurrence at a depth may not be directly due to productivity at the time but, rather, later migrated and precipitated barium triggered by sulfate reduction [26]. Zhou et al. [12] compared the contents of $\mathrm{Ba}_{\text {bio }}$ near the Guanyinqiao Member in the profiles of the Wangjiawan profile in Yichang and the Nanbazi profile in Tongzi. The results show that the content of $\mathrm{Ba}_{\mathrm{bio}}$ in the Wangjiawan profile is significantly higher than that in the Nanbazi profile, which barely contains any $\mathrm{Ba}_{\text {bio. }}$. In addition, the $\mathrm{Ba}_{\text {bio }}$ of the Nanbazi profile reaches a vertical minimum in the Guanyinqiao Member [12]; this observation is in contrast to that observed in the Guanyinqiao Member of the Wangjiawan profile $[12,18]$. The organic-rich shales of the Wufeng and Longmaxi Formations in the numerous profiles, including the Wangiiawan profile in Yichang, the Nanbazi profile in Tongzi, and the Shuanghe profile in Changning, as well as the drilling well, are all revealed to be intercalated with multiple layers of K-bentonites $[9,27,28]$. This suggests that volcanic ash precipitated homogenously in the Upper Yangtze region. If the enhanced sea productivity was due to volcanic ash, it would not have generated the productivity difference in the above profiles. Therefore, such a difference in productivity suggests that volcanic ash would not have been the reason for the high productivity of the sea surface.

\subsection{Upwelling Model}

\subsubsection{Evidence of Upwelling Formation}

Upwelling is an oceanographic phenomenon that cooler, and nutrient-rich water moves towards the ocean surface, replacing the warm and usually nutrient-depleted surface water [29]. In the areas on the western side of several continents, including the modern East Pacific Peru coastal area, East Atlantic Mauritania, and Namibia coastal area, the surface sea water flows away from the coast under the influence of northeast trade winds or southeast trade winds, whereas the lower levels of sea water rise to replenish the system, thereby forming an upwelling. Thus, the western side of a continent is a favorable area for the formation of an upwelling [30,31]. In an upwelling zone, upwelling brings nutrients from the sea bottom to its surface, promoting the mass reproduction of organisms and thus significantly increasing the primary productivity of the sea surface. In particular, during the La Niña (anti-El Niño) period, the southeast trade wind intensifies near the equator, and the rise of bottom seawater is stronger; thus, the fisheries along the coast of Peru achieve excellent harvests during the La Niña period. The biogenic silica on the modern sea floor is mainly present in areas that experience upwelling with high levels of high marine productivity, such as the zone surrounding the Antarctic circle, equatorial Pacific, North Pacific, and western coasts of continents. As a result, a large amount of siliceous organism growth is generally considered to be an important indicator of an upwelling area [31,32]. An upwelling is associated with the characteristics of low temperature; for example, the sea surface temperature of the Oregon coastal upwelling area in the western US is $8^{\circ} \mathrm{C}$ lower than that of the nearby sea water [30]. The low sea temperature can cause the growth of cold-water organisms in such an area, leading to communities of organisms that vary significantly from those of nearby non-upwelling areas. Therefore, the growth of cold-water organisms in warm sea areas can also be taken as a marker of an upwelling formation [33]. In addition, the enrichment of organic matter, $U$, and Ba is also an important characteristic of an upwelling area; however, this characteristic is not limited to upwelling areas. This study mainly focuses on the paleogeographic location and characteristics of organism growth and suggested that the study area meeted the conditions of an upwelling formation and, appropriately, depicted characteristics that are typical of upwelling in the study area.

(1) Paleogeographic location. The Upper Yangtze region during the sedimentary period of the organic-rich shales in the Wufeng and Longmaxi Formations was located near the equator, marking the east margin of the paleo-Tethys Ocean. The region was located within what would have been the southeast trade wind zone or northeast trade wind zone to the west of the continent Gondwana. The Upper Yangtze region was a semi-closed sea that opened to the west during the sedimentary 
period of the organic-rich shales in the Wufeng and Longmaxi Formations; that is, the north margin of the modern Upper Yangtze region was the west margin of the late Ordovician-early Silurian Upper Yangtze region [34]. The features of this location are similar to those of the modern Peru coastal area. In addition, the paleo-Tethys is similar to the modern Pacific. Thus, the Upper Yangtze region was a favorable area for upwelling formation. The Wufeng and Longmaxi Formations of the Upper Yangtze region records a large number of storm deposits, including the tear-fragments of the near-source storm deposits and the hummocky cross bedding from distant storm deposits [35-37]. The abundant records of storm deposits indicate that storms were prevalent in the Upper Yangtze region during the late Ordovician-early Silurian. Based on modern weather observations, the Upper Yangtze sea meeted the conditions needed to form strong offshore winds, which in turn promoted the development of upwelling. Therefore, the Upper Yangtze region meeted the objective conditions for an upwelling formation (Figure 7).

(2) Characteristics of organismal growth. The analysis of the silica characteristics and previous data prove the enrichment of siliceous organisms including siliceous Radiolaria and siliceous sponge spicules in the organic-rich shales of the Wufeng and Longmaxi Formations, which is the important evidence of the existence of past upwelling in the Upper Yangtze region. The structural characteristics of siliceous Radiolaria reflect a cold-water environment $[19,20]$, suggesting that upwelling caused the low sea temperature in the Upper Yangtze region. In addition, the Hirnantian Brachiopoda that is abundant in the Guanyinqiao Member is a typical cold-water organism, suggesting that cold upwelling occurred in the Yangtze region [33].

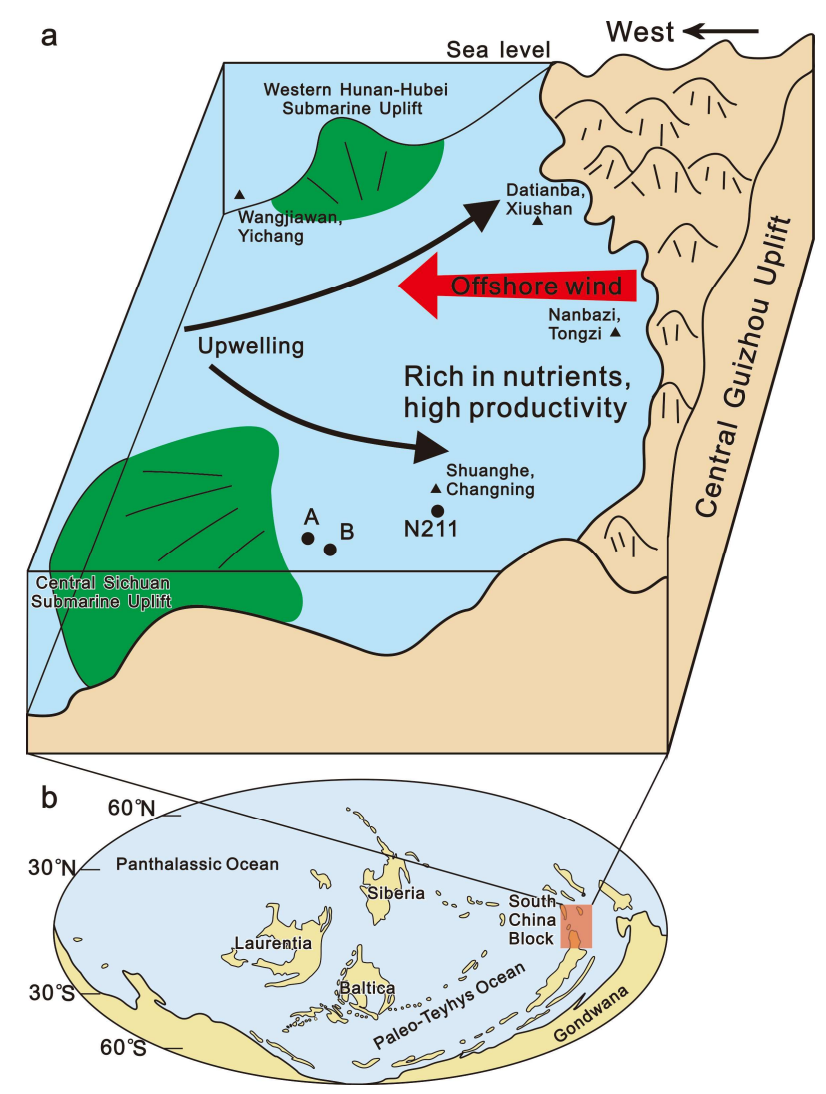

Figure 7. Upwelling formation model during the sedimentary period of the organic-rich shales in the Wufeng and Longmaxi Formations of the Upper Yangtze region. (a) Upwelling formation model; (b) Location of the South China Block (based on the results of Zhou et al. [12]).

Therefore, based on the favorable paleogeographic location of the Upper Yangtze region, the abundant siliceous organisms in the shales and the low sea temperature reflected by the characteristics of the paleo-organisms documented in the region, we determined that upwelling occurred in the Upper 
Yangtze region during that time. As discussed above, according to previous data [34-37], we believed that offshore wind was developed in the Upper Yangtze region. Under the influence of offshore wind during the sedimentary period of the organic-rich shales in the Wufeng and Longmaxi Formations, the surface sea water around the Upper Yangtze sea flowed westward to form the surface current, leading to the depletion of surface sea water. The mid-depth water of the paleo-Tethys Ocean rose to the Upper Yangtze sea via the west margin of the Upper Yangtze region (i.e., the modern north margin of the Upper Yangtze) as compensatory flow, leading to the formation of upwelling in the Upper Yangtze sea basin. This in turn led to nutrient enrichment (Figure 7) and sea surface productivity enhancement. In addition, the quartz content and TOC content were positively correlated, suggesting that upwelling provided a source of organic matter for the shale and played an important role in organic matter enrichment.

4.4.2. The Effect of Upwelling on the Organic Matter Enrichment of the Shales in the Wufeng and Longmaxi Formations

This study mainly used logging data from Well N211 to describe the variation of upwelling intensity during the sedimentary period of the organic-rich shales in the Wufeng and Longmaxi Formations of the Upper Yangtze region. In combination with previous data, we also described the horizontal changes associated with upwelling in the sedimentary period of the Guanyinqiao Member. The horizontal and vertical changes in upwelling led to the changes observed in the degree of organic enrichment.

Because biogenic silica in the organic-rich shales accounts for $67-90 \%$ of the silica content [24], the silica content could be used to approximate the upwelling intensity. In addition to (calcareous) siliceous shales, most areas of the Guanyinqiao Member also contain limestone deposits, suggesting that terrigenous input was rather sparse during that period. The silica content was observed to peak in the Guanyinqiao Member, suggesting that the peak of silica content in the Guanyinqiao Member was not due to terrigenous input but, in contrast, was associated with the increase of biogenic silica due to enhanced upwelling. Therefore, when the silica content peaks in the Guanyinqiao Member, the TOC content also peaks. The consistent vertical changes observed for the silica content, $\mathrm{P}_{2} \mathrm{O}_{5} / \mathrm{TiO}_{2}$ ratio, TOC content, GR value, and $U$ content in the first organic-rich layer of Well N211 suggest that the upwelling intensity gradually increased from the sedimentary period of the organic-rich shales in the mid-lower Wufeng Formation to the sedimentary period of the Guanyinqiao Member, reached a maximum in the sedimentary period of the Guanyinqiao Member, and then decreased gradually from the sedimentary period of the Guanyinqiao Member to the sedimentary period of the organic-rich shales in the Longmaxi Formation. The TOC content, GR value, and U content of the second organic-rich layer of Well N211 were lower than those of the first organic-rich layer and might suggest that upwelling weakened and the biogenic silica; thus, decreased during the sedimentary period of this shale. The rapid increase of clay mineral content in this shale, in contrast to the first organic-rich layer, suggest that terrigenous input increased, and the terrigenous silica could have increased; thus, there was no significant decrease of silica content in the second layer although the biogenic silica decreased. The upward decreased of TOC content, GR value, and U content in the second organic-rich layer suggested that upwelling weakened during the deposition of the second organic-rich layer. Overall, these results suggest that the upwelling intensity of the Upper Yangtze region first increased and then decreased in strength. The TOC content, GR value, and U content also increased first and then decreased (Figure 3).

The Guanyinqiao Member is divided into three lithofacies in the Upper Yangtze region. The siliceous shale facies and calcareous siliceous shale facies of the Guanyinqiao Member are characterized by a high TOC content and GR value, whereas the limestone facies of the Guanyinqiao Member possess a low TOC content and GR value [16]. As stated above, the GR value, silica content, TOC content, and $\mathrm{P}_{2} \mathrm{O}_{5} / \mathrm{TiO}_{2}$ ratio of Well $\mathrm{N} 211$ peaked in the Guanyinqiao Member due to upwelling enhancement. However, another question arises: How do we explain the organic depletion of the limestone facies in 
the Guanyinqiao Member? Take the Datianba profile in Xiushan near the central Guizhou uplift as an example. Its quartz content and TOC content are low in the Guanyinqiao Member [38] (Figure 8a). The lithology of this area is limestone. Zhao et al. [39] classified the Guanyinqiao Member of this profile as shallow beach facies. We suggested that the water depth was shallow in this area and that the upwelling effect was either non-existent or weak. The presence of Hirnantian Brachiopoda reflects the existence of low-temperature upwelling [33]; however, the Hirnantian Brachiopoda did not develop universally throughout the Guanyinqiao Member of the Upper Yangtze region. The near-shore Guanyinqiao Member, which is close to the central Guizhou uplift, is a limestone facies that developed with warm-water organisms such as coral, whereas the offshore siliceous shale facies developed with cold-water organisms that were dominated by Hirnantian Brachiopoda. This result demonstrates the characteristic development of cold-water organisms offshore and warm-water organisms nearshore $[40,41]$. Such a characteristic suggests that the cold upwelling did not affect the nearshore limestone facies and thus led to the low quartz content and TOC content in the Guanyinqiao Member of the area (Figure 8b). During the sedimentary period of the organic-rich shales in the Longmaxi Formation, sea level rose rapidly, and upwelling formed again in the nearshore area, which led to the observed maximum changes in quartz content and TOC content.

a

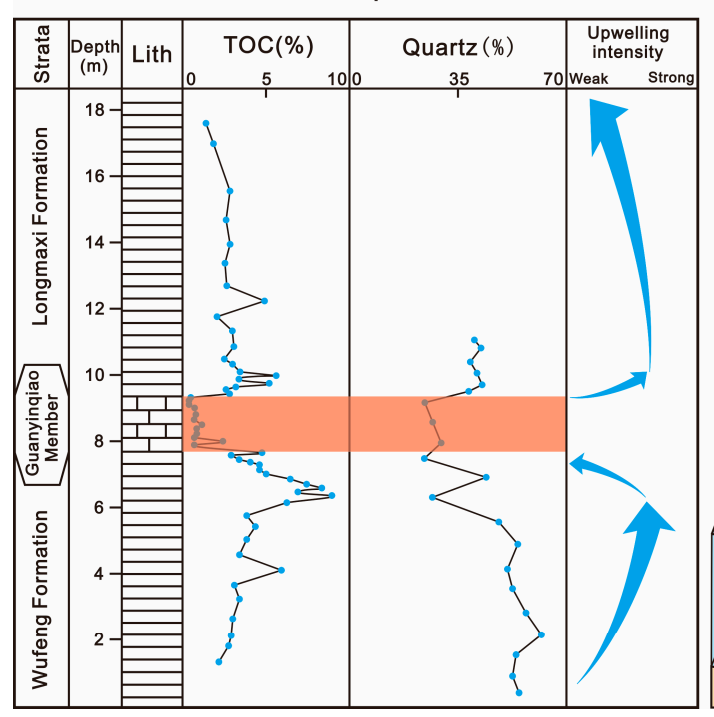

b

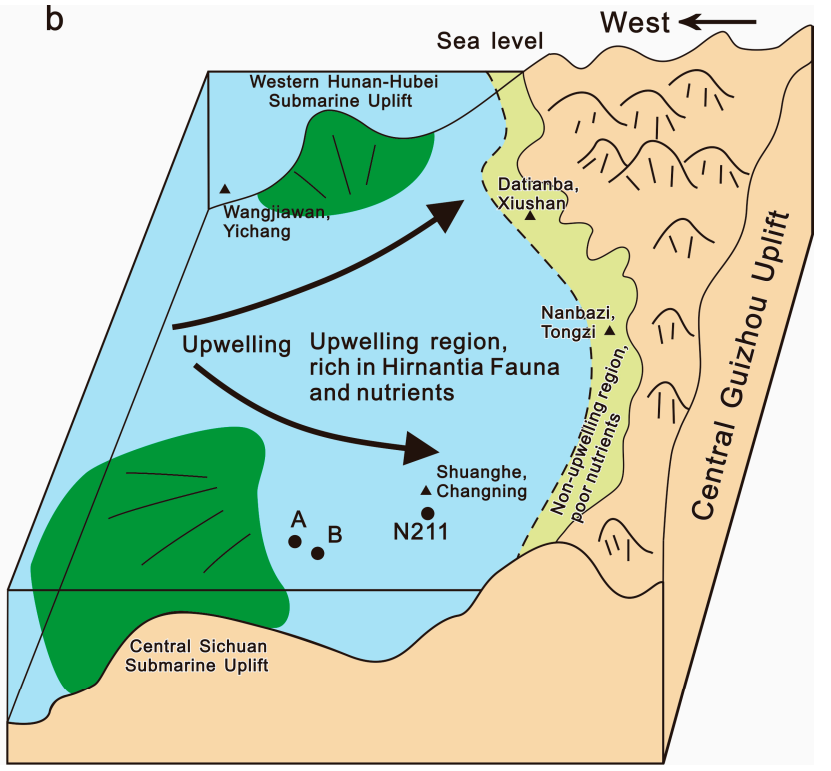

Figure 8. Different developments of upwelling in the Upper Yangtze region during the sedimentary period of the Guanyinqiao Member. (a) Stratigraphic profile of the Wufeng and Longmaxi Formations of Datianba (data for the Datianba profile are based on the results of Liu [38]); (b) Different developmented of upwelling in the Upper Yangtze region.

In conclusion, the upwelling intensity of the Upper Yangtze region first increased and then decreased in strength. Such changes in upwelling intensity led to the changes observed in the degree of organic enrichment, and might be due to the occurrence of a Paleozoic La Niña event during the sedimentary period of the organic-rich shales in the Wufeng and Longmaxi Formations. When La Niña was strongest, the offshore wind was most developed, leading to the strongest upwelling. Therefore, the Yangtze region during the sedimentary period of the Guanyinqiao Member might have been impacted by a strong La Niña. Based on this, we can interpret our observations: Although the shale thickness of the Wufeng and Longmaxi Formations can be as great as $500 \mathrm{~m}$, nonetheless, the organic-rich shale is concentrated in the lower tens of meters of the siliceous shale. The different developments of upwelling in the study area during the sedimentary period of the Guanyinqiao Member caused the coexistence of high and low TOC content in the Guanyinqiao Member. The TOC content and $\mathrm{Ba}_{\mathrm{bio}}$ content in the organic-rich shales of the Wufeng and Longmaxi Formations of the Wangjiawan 
profile are significantly higher than those of the Nanbazi profile [12], which also suggests that due to the effects of paleogeography, the different developments of upwelling in the study area led to the significant differences in TOC content and $\mathrm{Ba}_{\text {bio }}$ content, although the difference was observed to be more significant in the shallowest sedimentary period of the Guanyinqiao Member. According to this conclusion, we can judge that the area with high TOC content in Guanyinqiao Member is a potential area for high-quality shale development, because the area is continuously affected by upwelling.

\section{Conclusions}

(1) The organic-rich shales of Upper Yangtze Well N211 are located at the lower layer of the Wufeng and Longmaxi Formations, with a burial depth between $2308-2357 \mathrm{~m}$. This shale section could be divided into two layers. In the first shale layer, described by a burial depth between $2333-2357 \mathrm{~m}$, the GR value, $\mathrm{U}$ content, TOC content, and gas content were quite high. In the second shale layer, characterized by a burial depth between $2308-2333 \mathrm{~m}$, the GR value, U content, TOC content, and gas content were lower than those of the first layer. Moreover, in the vertical direction, the GR value, $\mathrm{U}$ content, TOC content, and silica content in the first layer increased gradually from the mid-lower Wufeng Formation to the top Guanyinqiao Member, reached their maxima in the Guanyinqiao Member before decreased gradually from the Guanyinqiao Member to the Longmaxi Formation. The GR value, $\mathrm{U}$ content, and TOC content in the second layer gradually decreased upward.

(2) Analysis of the microscopic characteristics and the mineral components showed that the Wufeng and Longmaxi Formations was enriched in siliceous organisms, such as Radiolaria and sponge spicules.

(3) Changes in sea level were not the only factor affecting organic matter enrichment. The paleo-location of the Upper Yangtze region, the abundant siliceous organisms in the shale, and the low sea temperature, as reflected by the region's biological characteristics, all indicate that the Upper Yangtze region developed upwelling during the sedimentary period of the organic-rich shales in the Wufeng and Longmaxi Formations. In addition, the positive correlation between the quartz content and TOC content suggests that upwelling provided a source of organic matter, which is an important factor for organic enrichment.

(4) Upwelling intensity increased gradually from the sedimentary period of the organic-rich shales in the mid-lower Wufeng Formation, reached a maximum during the sedimentary period of the Guanyinqiao Member and then decreased gradually from the sedimentary period of the Guanyinqiao Member to the sedimentary period of the organic-rich shales in the Longmaxi Formation. A Paleozoic La Niña phenomenon might have occurred during the sedimentary period of the organic-rich shales in the Wufeng and Longmaxi Formations. During this La Niña period, upwelling was most developed and had the highest productivity, thereby promoting organic enrichment in the shale deposits. The different developments of upwelling led to obvious differences in TOC content and Babio content in the Upper Yangtze region, which were more obvious during the sedimentary period of the Guanyinqiao Member with the shallowest seawater, so that the Guanyinqiao Member was characterized by the coexistence of both high and low TOC contents along the vertical direction.

Author Contributions: For this research article the specifying of the individual contributions of the authors is as follows: Conceptualization, methodology, and writing of the paper, S.-Z.Z., Y.L., and H.-J.M.; field geological investigation and sample collection, S.-Z.Z., J.-Z.Q., Z.-Z.Z., J.-C.W., and J.-P.W.; resources, T.W. and Z.N.; sample testing, S.-Z.Z., H.-J.M., T.W., and Z.N.; funding acquisition, Y.L.

Funding: This study was supported by Sichuan Science and Technology Program (grant number 2019YJ0468, 2017JY0140), Project of PetroChina Dagang Oilfield Company (grant number DGYT-2018-JS-289), and Geological Survey Project of China Geological Survey (grant number 121201010000150004-08).

Conflicts of Interest: The authors declare no conflict of interest. 


\section{References}

1. Wang, Y.M.; Li, X.J.; Dong, D.Z.; Zhang, C.C.; Wang, S.F. Major controlling factors for the high-quality shale of Wufeng-Longmaxi Formation, Sichuan Basin. Energy Explor. Exploit. 2017, 35, 444-462. [CrossRef]

2. Qiu, Z.; Jiang, Z.G.; Dong, D.Z.; Shi, Z.S.; Lu, B.; Tan, X.; Zhou, J.; Liang, P.P.; Wei, H.Y. Organic matter enrichment model of the shale in Wufeng-Longmachi formation of Wuxi area. J. China Univ. Min. Technol. 2017, 46, 1134-1143.

3. Yan, D.T.; Chen, D.Z.; Wang, Q.C.; Wang, J.G. Geochemical changes across the Ordovician-Silurian transition on the Yangtze Platform, South China. Sci. China. Ser. D Earth Sci. 2009, 52, 38-54. [CrossRef]

4. Li, Y.F.; Zhang, T.W.; Ellis, G.S.; Shao, D.Y. Depositional environment and organic matter accumulation of Upper Ordovician-Lower Silurian marine shale in the Upper Yangtze Platform, South China. Palaeogeogr. Palaeoclimatol. Palaeoecol. 2017, 466, 252-264. [CrossRef]

5. Chen, C.; Mu, C.L.; Zhou, K.K.; Liang, W.; Ge, X.Y.; Wang, X.P.; Wang, Q.Y.; Zheng, B.S. The geochemical characteristics and factors controlling the organic matter accumulation of the Late Ordovician-Early Silurian black shale in the Upper Yangtze Basin, South China. Mar. Pet. Geol. 2016, 76, 159-175. [CrossRef]

6. Zou, C.N.; Dong, D.Z.; Wang, Y.M.; Li, X.J.; Huang, J.L.; Wang, S.F.; Guan, Q.Z.; Zhang, C.C.; Wang, H.Y.; Liu, H.Y.; et al. Shale gas in China: Characteristics, challenges and prospects (I). Pet. Explor. Dev. 2015, 42, 753-767. [CrossRef]

7. Liu, Y.; Li, C.; Algeo, T.J.; Fan, J.X.; Peng, P.A. Global and regional controls on marine redox changes across the Ordovician-Silurian boundary in South China. Palaeogeogr. Palaeoclimatol. Palaeoecol. 2016, 463, 180-191. [CrossRef]

8. Meng, Z.Y. Vertical heterogeneity and its controlling factors of the gas shale in the Wufeng-Longmaxi Fms in Fuling area, the Sichuan Basin. Oil Gas Geol. 2016, 37, 838-846.

9. Lu, B.; Qiu, Z.; Zhou, J.; Dong, D.Z.; Wang, H.Y.; Xue, H.Q.; Zhou, S.W. The characteristics and geological significance of the K-bentonite in Wufeng Formation and Longmaxi Formation in Sichuan Basin and its peripheral areas. Chin. J. Geol. 2017, 52, 186-202.

10. Wu, L.Y.; Lu, Y.C.; Jiang, S.; Liu, X.F.; He, G.S. Effects of volcanic activities in Ordovician Wufeng-Silurian Longmaxi period on organic-rich shale in the Upper Yangtze area, South China. Pet. Explor. Dev. 2018, 45, 862-872. [CrossRef]

11. Pedersen, T.F.; Calvert, S.E. Anoxia vs. productivity: What controls the formation of organic-carbon-rich sediments and sedimentary rocks? AAPG Bull. 1990, 74, 454-466.

12. Zhou, L.; Algeo, T.J.; Shen, J.; Hu, Z.F.; Gong, H.M.; Xie, S.C.; Huang, J.H.; Gao, S. Changes in marine productivity and redox conditions during the Late Ordovician Hirnantian glaciation. Palaeogeogr. Palaeoclimatol. Palaeoecol. 2015, 420, 23-234. [CrossRef]

13. Yan, D.T.; Wang, Q.C.; Chen, D.Z.; Wang, J.G.; Wang, Z.Z. Sedimentary Environment and Develooment Controls of the Hydrocarbon Sources Beds: the Upper Ordovician Wufeng Formation and the Lower Silurian Longmaxi Formation in the Yangtze Area. Acta Geol. Sin. 2008, 82, 321-327.

14. Mu, C.L.; Zhou, K.K.; Liang, W.; Ge, X.Y. Early Paleozoic Sedimentary Environment of Hydrocarbon Source Rocks in the Middle-Upper Yangtze Region and Petroleum and Gas Exploration. Acta Geol. Sin. 2011, 85, $526-532$.

15. Jin, Z.J.; Hu, Z.Q.; Gao, B.; Zhao, J.H. Controlling factors on the enrichment and high productivity of shale gas in the Wufeng-Longmaxi Formations, southeastern Sichuan Basin. Earth Sci. Front. 2016, 23, 1-10.

16. Wang, Y.M.; Dong, D.Z.; Huang, J.L.; Li, X.J.; Wang, S.F. Guanyinqiao Member lithofacies of the Upper Ordovician Wufeng Formation around the Sichuan Basin and the significance to shale gas plays, SW China. Pet. Explor. Dev. 2016, 43, 45-53. [CrossRef]

17. Rong, J.Y.; Chen, X.; Zhan, R.B.; Fan, J.X.; Wang, Y.; Zhang, Y.D.; Li, Y.; Huang, B.; Wu, R.C.; Wang, G.X.; et al. New observation on Ordovician-Siliurian boundary strata of southern Tongzi County, Northern Guizhou, Southwest China. J. Stratigr. 2010, 34, 337-348.

18. Yan, D.T.; Wang, J.G.; Wang, Z.Z. The biogenic barium characteristics and paleoproductive significance of Upper Ordovician-Lower Silurian in the Yangtze area. J. Xi'an Shiyou Univ. (Nat. Sci. Ed.) 2009, 24, 16-19. 
19. Gao, Z.Z.; He, Y.B.; Li, L.Z.; Qing, C.W.; Xiao, M.G.; Cheng, S.H.; Zhang, W.C.; Liu, W.W. Genesis of the Guanyinqiao Member of Upper Ordovician Wufeng Formation in southern China: "Shallow water shelly facies" or deep-water allogenic deposition? J. Palaeogeogr. 2008, 10, 487-494.

20. Lu, L.F.; Qin, J.Z.; Shen, B.J.; Tenger; Liu, W.X.; Zhang, Q.Z. The origin of biogenic silica in siliceous shale from Wufeng-Longmaxi Formations in the Middle and Upper Yangtze region and its relationship with shale gas enrichment. Earth Sci. Front. 2018, 25, 1-11.

21. Zhao, J.H.; Jin, Z.J.; Jin, Z.K.; Hu, Q.H.; Hu, Z.Q.; Du, W.; Yan, C.N.; Geng, Y.K. Mineral types and organic matters of the Ordovician-Silurian Wufeng and Longmaxi Shale in the Sichuan Basin, China: Implications for pore systems, diagenetic pathways, and reservoir quality in fine-grained sedimentary rocks. Mar. Pet. Geol. 2017, 86, 655-674. [CrossRef]

22. Wang, S.F.; Zou, C.N.; Dong, D.Z.; Wang, Y.M.; Huang, J.L.; Guo, Z.J. Biogenic silica of organic-rich shale in Sichuan Basin and its significance for shale gas. Acta Sci. Nat. Univ. Pekin. 2014, 50, 476-486.

23. Ran, B.; Liu, S.G.; Jansa, L.; Sun, W.; Yang, D.; Ye, Y.H.; Wang, S.Y.; Luo, C.; Zhang, X.; Zhang, C.J. Origin of the Upper Ordovician-lower Silurian cherts of the Yangtze block, South China, and their palaeogeographic significance. J. Asian Earth Sci. 2015, 108, 1-17. [CrossRef]

24. Ma, Y.S.; Cai, X.Y.; Zhao, P.R. China's shale gas exploration and development: Understanding and practice. Pet. Explor. Dev. 2018, 45, 589-603. [CrossRef]

25. Zhang, L.N.; Fan, J.X.; Chen, Q. Geographic distribution and palaeogeographic reconstruction of the Upper Ordovician Kuanyinchiao Bed in South China. Chin. Sci. Bull. 2016, 61, 2053-2063.

26. Torres, M.E.; Brumsack, H.J.; Bohrmann, G.; Emeis, K.C. Barite fronts in continental margin sediments: A new look at barium remobilization in the zone of sulfate reduction and formation of heavy barites in diagenetic fronts. Chem. Geol. 1996, 127, 125-139. [CrossRef]

27. Hu, Y.H.; Sun, W.D.; Ding, X.; Wang, F.Y.; Ling, M.X.; Liu, J. Volcanic event at the Ordovician-Silurian boundary: The message from K-bentonite of Yangtze Block. Acta Petrol. Sin. 2009, 25, 3298-3308.

28. Su, W.B.; He, L.Q.; Wang, Y.B.; Gong, S.Y.; Zhou, H.Y. K-bentonite beds and high-resolution integrated stratigraphy of the uppermost Ordovician Wufeng and the lowest Silurian Longmaxi formations in South China. Sci. China Ser. D Earth Sci. 2003, 46, 1121-1133. [CrossRef]

29. Chang, H.W.; Francis, A.S.; Dayou, J.; Sentian, J.; Chee, F.P. Upwelling event characteristics of chlorophyll-a concentration in the surface layer of Sabah waters. Indian J. Geo Mar. Sci. 2018, 47, 2532-2540.

30. Lü, B.Q. Introduction to Marine Geology; Tongji University Press: Shanghai, China, 2004; p. 181.

31. Ashckenazi-Polivoda, S.; Abramovich, S.; Almogi-Labin, A.; Schneider-Mor, A.; Feinstein, S.; Püttmann, W.; Berner, Z. Paleoenvironments of the latest Cretaceous oil shale sequence, Southern Tethys, Israel, as an integral part of the prevailing upwelling system. Palaeogeogr. Palaeoclimatol. Palaeoecol. 2011, 30, 93-108. [CrossRef]

32. Leinen, M.; Cwienk, D.; Heath, G.R.; Biscaye, P.E.; Kolla, V.; Thiede, J.; Dauphin, J.P. Distribution of biogenic silica and quartz in Recent deep-sea sediments. Geology 1986, 14, 199-203. [CrossRef]

33. Jin, J.S.; Zhan, R.B.; Wu, R.C. Equatorial cold-water tongue in the Late Ordovician. Geology 2018, 46, 759-762. [CrossRef]

34. Li, Y.; Ryo, M.; Steve, K. Sedimentary and biotic evidence of a warm-water enclave in the cooler oceans of the latest Ordovician glacial phase, Yangtze Platform, South China block. Island Arc 2005, 14, 623-635. [CrossRef]

35. Cheng, H.J.; Wang, Y.Z. The feature of sedimentary rocks near the Ordovician-Silurian boundary of the Fucheng area, Nanzheng County, Shanxi province. J. Xi'an Coll. Geol. 1991, 13, 1-7.

36. Li, W.H. Petrological Characteristics of Radiolarian Silicalite and Its Geological Significance of Lower Silurian in the Hanzhong Region. Acta Sedimentol. Sin. 1997, 15, 171-174.

37. Zhou, K.K.; Mu, C.L.; Liang, W.; Ge, X.Y. Tide-dominated Deltaic Deposits in Lungmachi Formation, Longshan-Yongshun Regions, Northwestern Hunan: The initial sedimentary responses to outset of "Xuefeng uplift". Acta Sedimentol. Sin. 2014, 32, 468-477.

38. Liu, Y. Development Environment and Shale Gas Resources Assessment of the Wufeng-Longmaxi Formation. Ph.D. Thesis, Guangzhou Institute of Geochemistry of Chinese Academy of Sciences, Guangzhou, China, 2016.

39. Zhao, M.S.; Wang, Y. Sedimentary Facies Features and Sea-level Fluctuation during the Upper Ordovician Hirnantian Period on the Southern Margin of the Upper Yangtze Sea. Acta Geosci. Sin. 2018, 39, 189-200. 
40. Wang, Y.C.; Liang, W.; Mu, C.L.; Zhou, K.K.; Ge, X.Y. The Sedimentary Response to Gondwana Glaciation in Hirnantian (Ordovician) of the Eastern Chongqing and the Northern Guizhou Region, South China. Acta Sedimentol. Sin. 2015, 33, 232-241.

41. Li, Y.; Wang, J.P.; Zhang, Y.Y.; Gu, C.H. The annotation on climate from the Ordovician-Silurian in South China. Prog. Nat. Sci. 2008, 18, 1264-1270. 